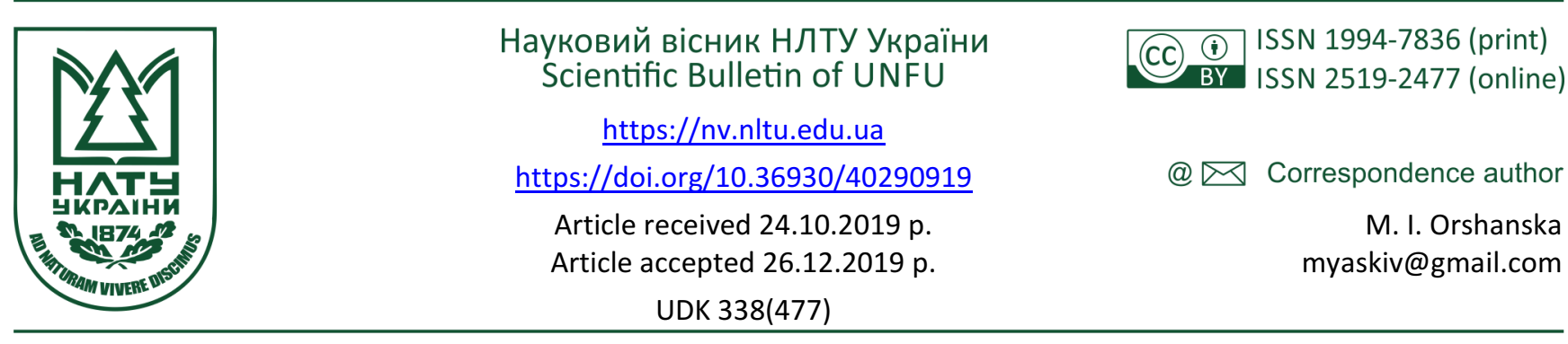

М. І. Орианська

Дрогобииький державний педагогічний університет ім. Івана Франка, м. Дрогобич, Украӥна

\title{
ЗАЛУЧЕННЯ ПРЯМИХ ІНОЗЕМНИХ ІНВЕСТИЦІЙ В ІНФРАСТРУКТУРУ УКРАЇНИ НА УМОВАХ ДЕРЖАВНО-ПРИВАТНОГО ПАРТНЕРСТВА
}

\begin{abstract}
Проаналізовано сучасні тенденції та особливості залучення прямих іноземних інвестицій за умов використання дієвих механізмів державно-приватного партнерства в Україні. Обгрунтовано потреба залучення прямих іноземних інвестицій в сучасних умовах, досліджено головні проблеми і перешкоди для ефективного функціонування проектів державно-приватного партнерства. Оцінено позитивний вплив та визначено пріоритетні принципи впровадження інститутів державно-приватного партнерства у вітчизняну практику реалізації інфраструктурних проектів задля підвищення ефективності та стандартів надання послуг суспільству. Практикою підтверджено, що різноманітність сфер, моделей та інструментів державно-приватного партнерства в галузі залучення прямих іноземних інвестицій робить його універсальним механізмом розв'язання довготермінових завдань і подолання проблем на шляху реалізації соціальних й інфраструктурних проектів загальнодержавного значення та розвитку нових перспективних технологій. Проаналізовано законодавчу базу, зроблено аналіз ефективності чинних законів, обгрунтовано потенційні загрози та можливості для змін, зростання та покращення роботи механізму державної підтримки та стимулювання інвестиційної привабливості, відкритості та легкості співпраці між державою та іноземними інвесторами. Доведено, що ефективне партнерство органів державної влади з приватним бізнесом спрямоване передовсім на забезпечення сталого розвитку та забезпечення стабільних темпів розвитку країни й окремих регіонів. Тому державно-приватне партнерство має стати визнаною альтернативою для фінансування суспільно важливих інфраструктурних проектів в Україні, зокрема способом залучення прямих іноземних інвестицій.
\end{abstract}

Ключові слова: іноземні інвестиції; державно-приватне партнерство; інфраструктура; концесія.

Вступ. Інфраструктура має вирішальне значення для економічного зростання, соціальної стабільності України, високого рівня розвитку на світовому ринку. Особливу роль у реалізації інфраструктурних проектів відіграє державно-приватне партнерство (ДПП). Впровадження ДПП в інфраструктуру - це нова якість управління інфраструктурою, що залучає провідний європейський досвід та технології, а також відкриває Україну компаніям зі світовим ім'ям, новими технологіями та фінансовими ресурсами. Про важливість ДПП свідчить те, що за сприяння Свропейського Банку Реконструкції та Розвитку (СБРР) з 2016 р. при Міністерстві інфраструктури України успішно функціонує Проектний офіс з питань державно-приватного партнерства в інфраструктурі - "SPILNO". Нині ДПП стає основною моделлю довготермінової співпраці держави та бізнесу, відкриваючи нові можливості для потенційних інвесторів і банків на одному з найбільших інфраструктурних ринків Центральної та Східної Свропи.

Аналіз останніх досліджень і публікацій. Проблему й особливості розвитку державно-приватного партнерства розглянуто в працях вітчизняних і зарубіжних учених: М. Авксєнтьєв, В. Варнавський, М. Джеррард, А. Корчагіна, І. Крейдич, К. Павлюк, С. Павлюк, О. Полякова, В. Пучков, П. Шилепницький, В. Якунін та ін. У численних дослідженнях вони аналізували з різних позицій механізми ефективної організації партнерства держави і бізнесу, інструменти залучення прямих іноземних інвестицій у різноманітні інфраструктурні проекти тощо.

Зокрема М. Авксєнтьєв здійснив узагальнювальний аналіз інституційних рішень та заходів правління різних країн для розвитку та підтримки сфери ДПП і запропонував систематизовані та класифіковані заходи для розбудови та вдосконалення цілісної державної політики у питаннях розвитку ДПП в Україні (Avksientiev, 2010). Ю. Бажал розглянув та порівняв переваги, які отримують малі та великі підприємства від інноваційної діяльності, підкреслив потреба державної підтримки малого бізнесу в інноваційній сфері (Bazhal, 2016). Ю. Срешко та Г. Яловий розробили й обгрунтували методологічні особливості розвитку підприємств на інвестиційно-інноваційних засадах в умовах трансформації економіки, запропонували методи і форми їх практичної реалізації, визначили напрями інвестиційно-інноваційного процесу національної економіки (Yereshko \& Yalovyi, 2014). I. Крейдич розробив принципово нові методичні підходи до організації та здійснення інвестиційної політики та запропонував процедури формування адекватної реальним виробничо-комерційним процесам системи прогнозних показників прямих іноземних інвестицій та інвестицій в основний капітал (DPP,

\section{Інформація про автора:}

Оршанська Мар'яна Іванівна, аспірант, кафедра економіки. Email: myaskiv@gmail.com

Цитування за ДСту: Оршанська М. І. Залучення прямих іноземних інвестицій в інфраструктуру України на умовах державноприватного партнерства. Науковий вісник НЛТУ України. 2019, т. 29, № 9. С. 110-115.

Citation APA: Orshanska, M. І. (2019). Attraction of direct foreign investments in Ukraine's infrastructure under public-private partnership. Scientific Bulletin of UNFU, 29(9), 110-115. https://doi.org/10.36930/40290919 
2019). С. Черевиков на підставі дослідження сучасного інструментарію фінансового забезпечення інфраструктурних проектів обгрунтував напрями вдосконалення механізмів фінансування інфраструктурних проектів 3 участю держави та приватного сектору в Україні (Husiev et al., 2017).

Об'єктом дослідження є співпраця між державою та іноземними партнерами.

Предметом дослідження є основні моделі співпраці між державою та іноземними партнерами.

Мета дослідження - проаналізувати сучасний стан розвитку державно-приватного партнерства та дослідити інструментарій залучення іноземних інвесторів задля реалізації проектів, спрямованих на вдосконалення й ефективність функціонування вітчизняної інфраструктури.

Для досягнення зазначеної мети потррібно вирішити такі основні завдання дослідження:

- дослідити питання щодо заснування державно-приватного партнерства, що стане одним із основних пріоритетних напрямів державних програм стратегічного розвитку;

- вияснити можливість адаптування чинного концесійного законодавства до європейських норм, що дасть можливість залучення у вітчизняну економіку приватних іноземних інвестицій;

- встановити можливість обрання приватного партнера для втілення проекту, що дасть змогу розширити генеруючі потужності українських об'єктів ядерної енергетики та підвищити ефективність енергоблоків.

Різноманітність сфер, моделей та інструментів ДПП робить його універсальним механізмом вирішення різних довготермінових проблем від реалізації соціальних та інфраструктурних проектів загальнодержавного значення до розвитку нових перспективних технологій Ефективне партнерство органів державної влади 3 приватним бізнесом спрямоване на забезпечення сталого розвитку та стабільних темпів розвитку країни й окремих регіонів. На жаль, орієнтація існуючих бюджетних стратегій і програм не дає змоги державним органам реалізовувати проекти великого, стратегічного рівня, які впливають на формування конкурентного потенціалу країни. Тому ДПП має стати визнаною альтернативою для фінансування суспільно важливих інфраструктурних проектів в Україні.

Викладення основного матеріалу. Сьогодення $\epsilon$ найсприятливіший для реалізації інструментів державно-приватного партнерства, які сприяють залученню приватного капіталу до інфраструктурних галузей України (Partnerstvo, 2016а). Для реалізації великих за обсягом новітніх проектів у різних сферах економіки необхідні значні інвестиційні активи, домінуючим джерелом яких може бути як держава та вітчизняний приватний бізнес, так й іноземні інвестори.

Державно-приватне партнерство в Україні - це система взаємодії між державними та приватними гравцями ринку, під час реалізації яких ресурси різних суб'єктів ринку об'єднуються з узгодженим розподілом ризиків, відповідальності та прибутків (відшкодувань) між ними, для взаємної користі через співпрацю на довготермінових умовах у створенні (відновленні) нових та/або осучасненні (реконструкції) наявних об'єктів, яким необхідне залучення інвестицій, та для використання (експлуатації) таких видів об'єктів (Proekt Zakonu, 2018).

ДПП грунтується на методах, які використовує державний сектор під час укладання угоди 3 приватним сектором. Суб'єкт господарювання використовує власні інвестиційні й управлінські можливості, реалізуючи складні інфраструктурні проекти та виконуючи умови угоди. Державний партнер надає необхідні якісні послуги для суспільства, впливаючи на розвиток економіки та підвищення рівня життя населення. Держава в процесі впровадження механізмів ДПП створює можливості для залучення приватних суб'єктів до секторів діяльності, які мають підвищений ризик, та залучення іноземних інвестицій у сфери, в яких приватний сектор не особливо зацікавлений (Partnerstvo, 2016b).

Автор розробив та подав у табл. 1 основні моделі ДПП (контакту, лізингу, угоди про розподіл продукції, кооперації та концесії), сфери їх застосування, власності й управління.

Табл. 1. Основні моделі державно-приватного партнерства

\begin{tabular}{|c|c|c|c|c|}
\hline Модель & Сфера & Застосування & Власність & Управління \\
\hline Модель контракту & $\begin{array}{c}\text { надання громадських послуг, постачан- } \\
\text { ня продукції для державних потреб }\end{array}$ & приватна/державна & приватна \\
\hline Модель лізингу & $\begin{array}{c}\text { оренда приватним партнером держав- } \\
\text { них об'єктів, виробничого обладнання }\end{array}$ & державна & приватна/державна приватна/державна \\
\hline $\begin{array}{c}\text { Модель угоди про } \\
\text { розподіл продукції }\end{array}$ & $\begin{array}{c}\text { аналіз та видобуток сировини приват- } \\
\text { ним сектором із майбутнім розподілом } \\
\text { продукції }\end{array}$ & державна & приватна \\
\hline Модель кооперації & $\begin{array}{c}\text { створення спільних державно-приват- } \\
\text { них підприємств, керівництво та } \\
\text { прийнятя відповідно внесків сторін }\end{array}$ & приватна/державна & приватна/державна приватна/державна \\
\hline Модель концесії & $\begin{array}{c}\text { здійснення масштабних, капіталоміс- } \\
\text { тких та соціально орієнтованих проектів }\end{array}$ & державна & приватна/державна \\
\hline
\end{tabular}

Варто наголосити на тому, що в умовах посткризового розвитку України інтерес багатьох бізнесових структур до державної підтримки зростає у геометричній прогресії, що створює можливість зменшити ризики приватних інвестицій, підвищити надійність та ефективність інвестиційних проектів для кредитних установ. Успішний та динамічний розвиток ДПП як механізму інтенсивнішого розвитку інвестиційної діяльності та введення приватних інвестицій у ключові для державного управління сфери їх застосування стане можли- вим можливе тільки тоді, коли буде забезпечений захищений баланс інтересів між державою та приватними інвесторами.

Згідно $з$ поданими даними центральних і місцевих органів виконавчої влади в Україні, станом на 1 липня 2019 р. на умовах ДПП укладено 186 договорів, з яких виконуються 52 договори (35 - договорів концесії, 15 договорів про спільну діяльність, 2 - інші договори) (Hammam et al., 2006). На рис. 1 зображено договори, укладені на засадах ДПП, у різних областях України. 


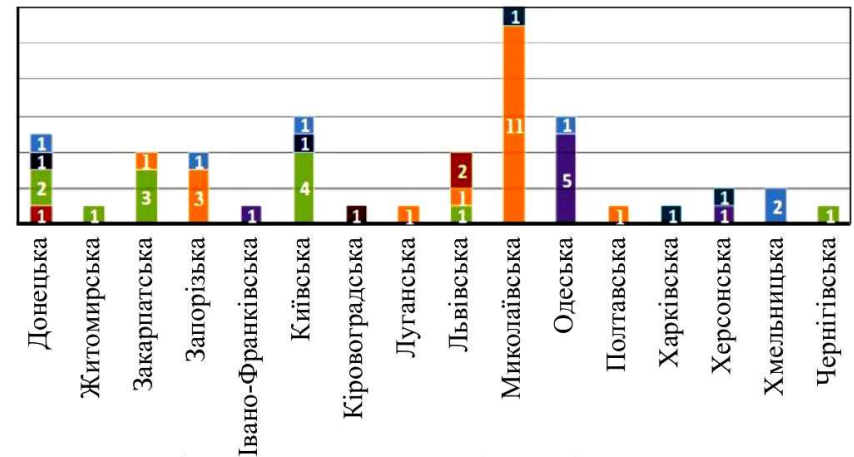

пошук, розвідка корисних - копалин

"інфраструктура

- охорона здоров'я

- обробка відходів

- управління нерухомістю

виробництво/транспортування "природного газу

" збір, очищення та розподіл води

- туризм

- виробництво електричної енергії =інші

Рис. 1. Розгорнуті статистичні дані укладених договорів ДПП в областях України на 1 липня 2019 р.

Механізм ДПП було запроваджено у правову площину в 2010 р. завдяки ухваленню Закону України "Про державно-приватне партнерство". Відтоді ринок ДПП перебуває на стадії становлення і розвитку. Динаміка зростання кількості проектів, реалізованих у межах ДПП, відповідно до статистики Міністерства економічного розвитку і торгівлі України у 2012-2016 рр. (Partnerstvo, 2019), свідчить про підвищення зацікавленості як приватної, так і державної сторін у правовій формі співпраці (рис. 2)

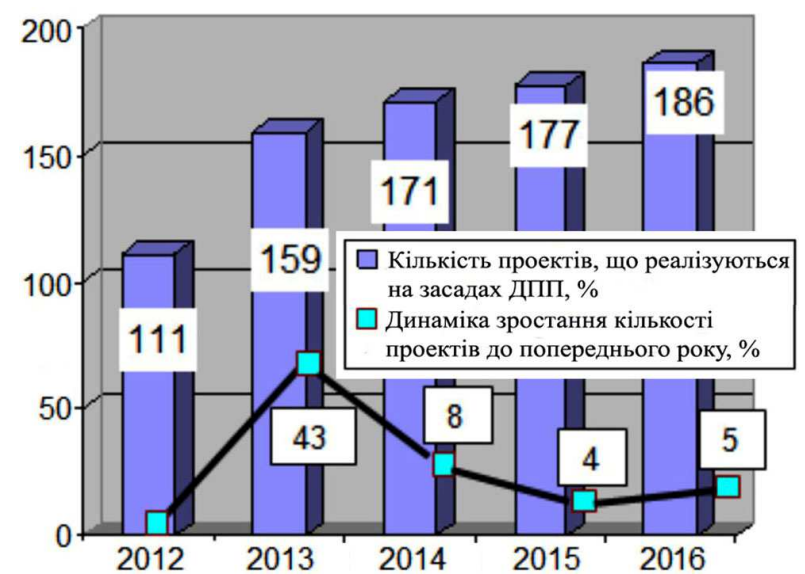

Рис. 2. Динаміка кількісного та відсоткового зростання проектів, які реалізувалися на засадах ДПП у 2012-2016 рр.

Серед договорів, укладених через механізми ДПП, переважають концесійні договори (табл. 2).

Табл. 2. Динаміка кількісного росту проектів у розрізі форм ДПП у 2012-2016 pp.

\begin{tabular}{|c|c|c|c|c|c|}
\hline \multirow{2}{*}{ ДПП } & \multicolumn{5}{|c|}{ Рік } \\
\cline { 2 - 6 } & 2012 & 2013 & 2014 & 2015 & 2016 \\
\hline Спільна іяльність & 32 & 31 & 33 & 31 & 33 \\
\hline Концесія & 79 & 128 & 138 & 146 & 153 \\
\hline Разом & 111 & 159 & 171 & 177 & 186 \\
\hline
\end{tabular}

До основних ознак ДПП, згідно з зі Законом України "Про державно-приватне партнерство" за № 2404VI, належать (Zakon Ukrainy, 2019): 1) створення можливостей для отримання вищих технічних та економічних показників від ведення діяльності, ніж у випадку ведення такої діяльності тільки державним партнером без використання потенціалу приватного партнера; 2) розвиток відносин на довготривалий проміжок часу (від 5 до 50 років); 3) перерозподіл частини ризиків на користь приватного партнера за умови реалізації державно-приватного партнерства; 4) залучення та застосовування приватним партнером різноманітних інвестиційних ресурсів в об'єкти партнерства із джерел, законодавство яких не забороняє.

Однак у більшості країн, які отримали позитивний досвід у цьому напрямі, однією з головних ознак ДПП є те, що цей механізм використовують для реалізації масштабних та інноваційних національних чи міжнародних проектів, що мають важливий соціальний аспект, зокрема для інфраструктурних інновацій. Світовий досвід показує та переконує, що ефективна взаємодія та співпраця між державним та приватним бізнесами має найбільший ефект, насамперед у галузях інфраструктури, де історично існують передумови, можливості та велика потреба у такому виді співпраці для введення у реалізацію та вирішення масштабних соціально важливих економічних проблем (Kreidych, 2010; Iossa \& Martimort, 2015).

Залучення приватного бізнесу й приватних інвесторів до розвитку різних галузей економіки є звичною практикою у багатьох країнах світу, оскільки в них завжди існує дефіцит бюджету. Так, третина загального обсягу інвестицій, що надходять на ринки країн, які розвиваються, зараз спрямовується на проекти державно-приватного партнерства. Тому Україні потрібно врахувати цю тенденцію та почати використовувати інструмент ДПП для активного залучення значних обсягів інвестиційних ресурсів та ефективного розвитку економіки (Shylepnytskyi, 2011).

Аналіз досвіду і перспектив використання різноманітних механізмів ДПП за кордоном свідчить, що у 2000-2010 рр. 29 країн Латинської Америки та Карибського басейну впровадили 688 інфраструктурних проектів загальною вартістю 191 млрд дол. США. Водночас 17 країн Східної Азії та Тихоокеанського регіону впровадили 908 проектів у галузі інфраструктури загальною вартістю 154 млрд дол. США. У 2014 р. в Європі для реалізації проектів ДПП було залучено 18,7 млрд євро (у 2013 р. - 16,3 млрд) (Vynnytskyi et al., 2008; Husiev et al., 2017; Market Update, 2019).

Динаміку розвитку ДПП в Європі, за даними Європейського центру з дослідження публічно-приватного партнерства (EPEC) (Market Update, 2019), зображено на рис. 3 .

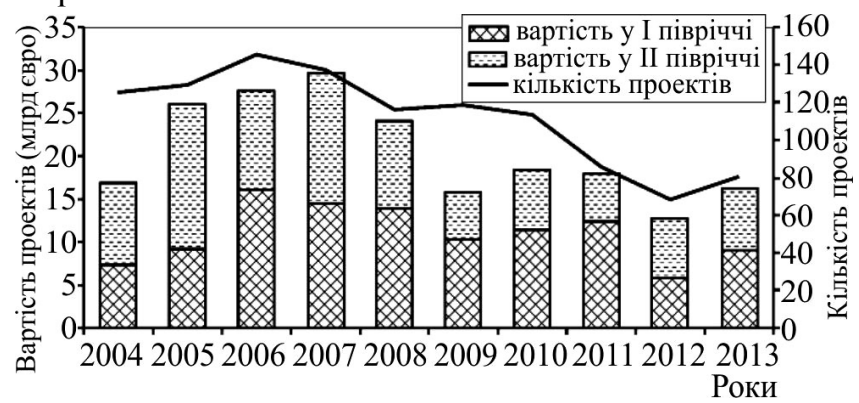

Рис. 3. Динаміка розвитку ДПП в Європі

Упровадження моделі ДПП для України є достатньо новим досвідом. Тому, маючи на меті швидке впровадження та ефективне функціонування моделі ДПП в Україні, при Міністерстві інфраструктури за промоцією Western NIS Enterprise Fund було утворено Проектний 
офіс 3 прогресивного розвитку державно-приватного партнерства в інфраструктурі "SPILNO". Беручи до уваги те, що ДПП є одним з важливих засобів результативного управління інфраструктурними об'єктами, для Проектного офісу було вирішальним основне завдання - ввести в дію механізм ДПП в Україні. При цьому важлива частина проекту, одне з перших завдань, це пошук змін для удосконалення українського законодавства, а також не менш важлива частина, що можна визначити як друге завдання, це підготовка та розвиток перших пілотних проектів для ефективної їх реалізації. Сьогодні за участі Проектного офісу "SPILNO" розпочато роботу над реалізацією таких пілотних концесійних проектів (Hammam et al., 2006): 1) проект на умовах договору концесії ДП "Стивідорна компанія "Ольвія"", який має за мету залучення інвестиційних коштів обсягом 17,3 млрд грн та зростання поступлень до різних ланок бюджетної системи близько 58 млрд грн за повний термін дії договору концесії, який триватиме 35 років, зокрема доходи від концесійних платежів - близько 19,5 млрд грн; 2) проект на умовах договору концесії ДП "Херсонський морський торговельний порт" з обсягом залучення інвестиційних коштів близько 1,37 млрд грн та зростання поступлень до різних ланок бюджетної системи до 14,3 млрд грн за повний термін дії договору концесії, який триватиме 30 років, у тому числі прибутків від концесійних платежів - до 2,8 млрд грн; 3) проект на умовах договору концесії залізнично-поромного комплексу ДП "Морський торговельний порт "Чорноморськ"" та ін.

Варто наголосити, що активне використання різноманітних механізмів ДПП сприятиме управлінню на якісно новому рівні інфраструктурними об'єктами передовсім у таких вагомих для розвитку країни сферах та галузях, як: морська інфраструктура, особливу увагу потрібно звернути на портову інфраструктуру, автомобільну промисловість, дороги на шляхи, аеропорти, а також важливою сферою є охорона здоров'я та галузь житлово-комунального господарства. 3 усієї сукупності транспортних галузей варто виділити портову інфраструктуру, оскільки сьогодні вона $є$ найближчою та найпривабливішою для реалізації проектів ДПП.

Важливими умовами в успішній реалізації концесійних угод на підставі ДПП, на наш погляд, є саме такі: 1) вигідне економіко-географічне положення на перетині міжнародних транспортних шляхів з Європою, величезний транзитний потенціал; 2) кваліфіковані кадри за дуже низькою вартістю, порівняно з європейськими країнами; 3) широко розвинена мережа водних терміналів - морських портів (13 портів різних за розміром та видами спеціалізації) 3 великими потужностями; 4) наявність широкого виходу до Чорного й Азовського морів, можливість використання водних магістралей, доступ до трьох великих судноплавних річок, значна прибуткова діяльність морських портів; 5) географічно вигідне розташування летовищ, розгалуженість аеропортів, розвиток та зростання рейсів у різні куточки світу, збільшення пасажиропотоків та вантажних перевезень, вагомий транзитний потенціал; 6) розгалужена залізнична мережа протяжністю 22 тис. км, 3 яких $45 \%$ електрифіковані; 7) розвинена мережа автомобільних шляхів, розгалужена сфера автомобільних перевезень, які охоплюють близько 40 \% пасажирських та близько $25 \%$ вантажних перевезень тощо.

Концесійна форма співпраці надзвичайно важлива i корисна форма залучення інвестицій. Одним із найважливіших проектів, який нині реалізується в Україні, є транспортний коридор GO Highway, покликаний з'єднати дорожню мережу України з європейською транспортною системою TEN-T.

Із 2020 р. розпочнеться другий етап модернізації, реконструкції та нового будівництва, за умовами якого буде розпочато будівництво першої платної концесійної дороги за напрямком Краковець - Львів. Інший проект ДПП "Енергетичний міст "Україна - СС", що має на меті інтеграцію енергетичної системи України до рівня європейської ENTSO-E, проходив тривалу чотирирічну процедуру погодження та знаходиться на завершальній стадії.

У січні 2019 р. планують проведення конкурсу для обрання приватного партнера для втілення проекту, що дасть змогу розширити генеруючі потужності українських об'єктів ядерної енергетики та підвищити ефективність енергоблоків.

В українському законодавстві існує велика кількість законодавчих актів, що регулюють діяльність у сфері відносин концесії державної та комунальної власності, a саме такі нормативні документи, як: Закон України "Про концесії", "Про концесії на будівництво та експлуатацію автомобільних доріг", "Про особливості здачі в оренду чи концесію об'єктів тепло- та водопостачання і водовідведення, що перебувають у комунальній власності", "Про особливості оренди чи концесії об'єктів паливно-енергетичного комплексу, що перебувають у державній власності".

Наявність розгалуженої кількості законодавчих актів створює додаткові труднощі в регулюванні процедурами ефективної реалізації проектів, найголовніші 3 яких: 1) складні та тривалі процедури укладання контрактів, концесійних угод тощо; 2) відсутність системи управління фіскальними та фінансовими ризиками сторін; 3) неякісний механізм щодо визначення вартості концесійних платежів, операційних (виробничих) витрат тощо.

Для вирішення цього питання за підтримки СБРР було створено та ухвалено 3 квітня 2018 р. у першому читанні найочікуваніший для інвесторів проект Закону України "Про концесії" (Cherevykov \& Ovcharova, 2013), що значно спрощує й полегшує реалізацію концесійних угод між державою та бізнесом. Такий підхід свідчить про те, що вдосконалена законодавчо-правова форма регулювання процесу здійснення ДПП повинна сприяти збільшенню для інвестора рівня привабливості, убезпечити процедуру вкладення коштів у державну власність та допомогти реалізувати головну мету проекту, а саме сприяти розвитку та розширенню сфер національної економіки, які мають важливе стратегічне значення для держави. 3 цією метою держава повинна сприймати приватного інвестора, особливо іноземного, як рівнозначного та рівноправного партнера. Водночас, вимагаючи та зобов'язуючи інвестора дотримуватись всіх правил, передбачених угодами зобов'язань, а також працювати у двосторонньому форматі, держава, зі свого боку, має гарантувати дотримання виконання в повному обсязі своїх власних зобов'язань. 
Позитивною зміною у сфері регулювання концесійної діяльності було ухвалення нового закону "Про концесію" № 155-ІХ" від 03.10.2019 р. (Kredisov \& Bilous, 2016), що має на меті вдосконалення та модернізацію правового регулювання відносин під час здійснення концесійної діяльності, гармонізацію законів про державно-приватне партнерство та концесію, що дасть поштовх до якісно нового управління та залучення інвестиційних ресурсів в інфраструктуру країни, ефективному використанню держаних та комунальних об'єктів, розбудови соціально важливих проектів та надання населенню якісних суспільних послуг.

\section{Висновки.}

1. З'ясовано, що останніми роками питання щодо заснування державно-приватного партнерства стало одним із основних пріоритетних напрямів державних програм стратегічного розвитку, показником результативної взаємодії бізнесових структур та органів державної влади, найефективнішим альтернативним способом відновлення, розширення та модернізації національної економіки.

2. Встановлено, що за умов розширення ДПП, адаптування чинного концесійного законодавства до європейських норм з'явиться можливість залучення у вітчизняну економіку, зокрема в численні інфраструктурні проекти, приватних іноземних інвестицій, що сприятиме значному скороченню рівня безробіття та зміцненню авторитету України як надійного та стабільного бізнеспартнера на міжнародних європейських інвестиційних ринках. Про це свідчать чинні концесійні угоди - транспортний коридор GO Highway, покликаний з'єднати дорожню мережу України $з$ європейською транспортною системою TEN-T; ДПП "Енергетичний міст "Україна - СС"", що має на меті інтеграцію енергетичної системи України до рівня європейської ENTSO-E, також очікується обрання приватного партнера для втілення проекту, що дасть змогу розширити генеруючі потужності українських об'єктів ядерної енергетики та підвищити ефективність енергоблоків.

3. Виявлено, що розпочато роботу над такими пілотними проектами, як: ДП "Стивідорна компанія "Ольвія"", ДП "Херсонський морський торговельний порт", ДП "Морський торговельний порт "Чорноморськ"", що сприятиме управлінню на якісно новому рівні інфраструктурними об'єктами морським галузям.

4. Встановлено, що різноманітність сфер, моделей та інструментів ДПП робить його універсальним механізмом вирішення різних довготермінових проблем від реалізації соціальних та інфраструктурних проектів загальнодержавного значення до розвитку нових перспективних технологій.

5. Доведено, що ефективне партнерство органів державної влади 3 приватним бізнесом спрямоване на забезпечення сталого розвитку та стабільних темпів розвитку країни й окремих регіонів. На жаль, орієнтація існуючих бюджетних стратегій i програм не дає змоги державним органам реалізовувати проекти великого, стратегічного рівня, які впливають на формування конкурентного потенціалу країни. Тому ДПП має стати визнаною альтернативою для фінансування суспільно важливих інфраструктурних проектів в Україні.

\section{References}

Avksientiev, M. Yu. (2010). Derzhavno-pryvatne partnerstvo yak suchasnyi mekhanizm zaluchennia investytsii v infrastrukturni haluzi Ukrainy. Abstract of Doctoral Dissertation for Economic Sciences (08.00.03 - Economics and Management of National Economy). Kyiv, 20 p. [In Ukrainian].

Bazhal, Yu. M. (2016). Mistse i rol maloho biznesu v innovatsiinii modeli ekonomichnoho rozvytku. (Ser. Ekonomika ta menedzhment). Problemy innovatsiino-investytsiinoho rozvytku, 9, 4346. [In Ukrainian].

Cherevykov, Ye. L., \& Ovcharova, L. P. (2013). Suchasnyi instrumentarii finansuvannia infrastrukturnykh proektiv. Naukovi pratsi NDFI, 1, 3-9. [In Ukrainian].

DPP. (2019). Ministerstvo ekonomichnoho rozvytku i torhivli Ukrainy. Stan zdiisnennia DPP $\mathrm{v}$ Ukraini. Retrieved from: https://www.me.gov.ua. [In Ukrainian].

Hammami, M., et al. (2006). Determinants of Public-Private Partnerships in Infrastructure. Retrieved from: https://imf.org/external/pubs/ft/wp/2006/wp0699.pdf.

Husiev, Yu., Boichuk, T., Khoroshun, A., Sadova, T., et al. (2017). Realizatsiia proektiv derzhavno-pryvatnoho partnerstva $v$ Ukraini. Kyiv: SPILNO, 94 p. [In Ukrainian].

Iossa, E., \& Martimort, D. (2015). The Simple Microeconomics of Public-Private Partnerships. Journal of Public Economic Theory, 17, 4-48.

Kredisov, A., \& Bilous, A. (2016). Derzhavno-pryvatne partnerstvo: svitovyi dosvid ta yoho vykorystannia v Ukraini. Ekonomika Ukrainy, 2(651), 4-15. [In Ukrainian].

Kreidych, I. M. (2010). Formuvannia ta realizatsiia investytsiinoi polityky rozvytku promyslovykh pidpryiemstv. avtoref. Abstract of Doctoral Dissertation for Economic Sciences (08.00.04 - Economy of Management of Property). Kyiv, 39 p. [In Ukrainian].

Market Update. (2019). Review of the European PPP Market in 2013. Retrieved from: https://www.eib.org/epec/resources/publications/ epec market update 2013 en.pdf.

Partnerstvo. (2016a). Derzhavno-pryvatne partnerstvo. Kyiv: Navch.metod. tsentr "Konsortsium iz vdoskonalennia, menedzhment - osvity v Ukraini". Retrieved from: https://issuu.com/ceume/docs/ppp2016_web1. [In Ukrainian].

Partnerstvo. (2016b). Derzhavno-pryvatne partnerstvo. Retrieved from: https://www.ebrd.com/infrastructure/infrastructurePPPs.com ta https://www.britannica.com/topic/public-private-partnership. [In Ukrainian].

Partnerstvo. (2019). Praktychnyi posibnyk z pidhotovky tekhniko-ekonomichnoho obgruntuvannia ta zastosuvannia metodyky provedennia analizu efektyvnosti zdiisnennia derzhavno-pryvatnoho partnerstva. Retrieved from: https://ppp-ukraine.org/wpcontent/uploads/2015/03/PracticalGuide.pdf. [In Ukrainian].

Proekt Zakonu. (2018). Pro kontsesii vid 15.05.2018 r., № 8125. Retrieved from: https://w1.c1.rada.gov.ua/pls/zweb2/webproc4_1?pf3511 $=63630$. [In Ukrainian].

Shylepnytskyi, P. I. (2011). Derzhavno-pryvatne partnerstvo: teoriia ta praktyka. Chernivtsi, 454 p. [In Ukrainian].

Vynnytskyi, B., Lendel, M., Onyshchuk, B., \& Sehvari, P. (2008). Dosvid ta perspektyvy vprovadzhennia derzhavno-pryvatnykh partnerstv v Ukraini ta za kordonom. Kyiv: K.I.S., 146 p. [In Ukrainian].

Yereshko, Yu. O., \& Yalovyi, H. K. (2014). Stokhastychni investytsii finansuvannia innovatsii na promyslovykh pidpryiemstvakh. Ekonomichnyi visnyk Natsionalnoho tekhnichnoho universytetu Ukrainy "Kyivskyi politekhnichnyi instytut", 11, 512-521. [In Ukrainian].

Zakon Ukrainy. (2010). Pro derzhavno-pryvatne partnerstvo vid 01.07.2010 r., № 2404-VI. Vidomosti Verkhovnoi Rady Ukrainy, 40. Retrieved from: https://zakon.rada.gov.ua/laws/show/2404-17 (Date of application: 28.08.2019). [In Ukrainian].

Zakon Ukrainy. (2019). Pro kontsesiiu vid 03.10.2019 r., № 155-IX. Retrieved from: https://zakon.rada.gov.ua/laws/show/155-ix. [In Ukrainian]. 


\section{ATTRACTION OF DIRECT FOREIGN INVESTMENTS IN UKRAINE'S INFRASTRUCTURE UNDER PUBLIC-PRIVATE PARTNERSHIP}

The article analyzes the economic nature of public - private partnership as a progressive form of business activity, examines current trends and features of attracting foreign direct investment in the use of effective mechanisms of public - private partnership in Ukraine, and the need to use promising forms of public - private partnership in certain segments of the economy. The necessity of attracting foreign direct investment in modern conditions is substantiated. The main problems and obstacles for the effective functioning of public-private partnership projects are investigated. The main forms of such model of public-private partnership as the concession, which has become the most popular among other forms of public-private partnership both in Ukraine and abroad, are identified. The mechanism of concession is investigated, which, being a subject to its proper legal and regulatory support, can be used for the implementation of large-scale infrastructure projects (port, rail, aviation and road), as well as for the effective ownership and management of state assets that are not subject to privatization. The promotion of public-private partnership is revealed to be one of the mechanisms for ensuring the sustainable development of Ukraine's economy and improving the investment climate, attracting foreign direct investment and developing the country as a whole. World experience shows that concessions can be successfully used to build infrastructure in a deficit of budget without increasing government debt. Practice has confirmed that the diversity of spheres, models and instruments of public-private partnerships in the field of attracting direct foreign investment makes it a universal mechanism for solving long-term problems and overcoming problems in the implementation of social and infrastructure projects. Concessions have been successfully used as an alternative to privatization in the port industry, and for the construction, modernization and management of airports. Concessions are being implemented to improve transport infrastructure, the unsatisfactory condition of which is an obstacle to harnessing Ukraine's enormous transit potential. Successful implementation of public-private partnership projects is proved to catalyze the inflow of foreign and domestic investments, and therefore, will become an incentive for large foreign investors to come to Ukraine with experience of concessions for construction and management of highways, modernization and management of ports, and airports, which are certainly better infrastructure. We have established that in order to remain a competitive country in the global market Ukraine has to develop its innovative technologies, including through its organization in the form of public-private partnership, and thus,should become one of the priority areas of development.

Keywords: foreign investment; public-private partnership; infrastructure; concession. 